\title{
COMPARISON OF SECTOR STOCK RETURNS CONSUMER AND CONSTRUCTION SECTOR COMPANIES ON THE INDONESIA STOCK EXCHANGE
}

\author{
Christian, Rinaldi Rustam \\ Faculty of Economic, Universitas Trisakti \\ Jl. Kyai Tapa No. 1, Grogol, Jakarta Barat, Indonesia \\ Correspondence E-mail: naldyrinaldi@yahoo.com \\ Received: July 2018; Accepted: October 2018
}

\begin{abstract}
This research attempts to analyze risk and stock return of Consumption for Goods Industry and Construction Industry at Indonesian Stock Exchange. This research used documentation method to collect data. Data has been taken from Bloomberg Terminal. The samples are 4 corporations, with two corporations for each industry from the year 2011 until 2016. This research used Capital Asset Pricing Model (CAPM) and Arbitrage Pricing Theory (APT) for data analysis. Analytically, the Capital Asset Pricing Model (CAPM) has poor overall explanatory power, whereas the Arbitrage Pricing Theory (APT) model allows multiple sources of systematic risks to be taken into account and performs better than the CAPM, in all the tests considered. The dependent variable used in this study is the stock return. The result showed that there is no effect between inflation and all of stocks used in research but has a different sign between consumer and construction with negative and positive effect respectively.
\end{abstract}

Keywords: CAPM, APT, Risk and Return of Stock.

JEL Classification: G12, G13, D81, C01

\section{INTRODUCTION}

The state economic development can be measured by knowing the grade of capital market development and security industries which placed on the state itself. A capital market is a place for a various party especially selling stock and bond in order to be used as an additional fund from the sales results or strengthen the company fund (Fahmi, 2009). Or according to Shim and Siegel (1999:68) stock market is a central trade for a long-term bond or firm's stock.

Common stock is ownership proof of the company (Husnan, 2009), the proof of the ownership whether it is incorporated/ limited liability company or public company (Gumanti, 2011). Usually, each share gives the holder the rights to vote at a general meeting of shareholders. In general, investment in stocks allows for higher returns compared to bonds, even though the risk involved is also higher.
Consumer goods are one of the attractive sectors to be an option for investment. Associated with the increase in world crude oil prices, this industry tends to survive because it is an industry to meet the daily needs which needed by the community. And construction is the foundation for the development of an area or country that supports the economic growth of the region and country. Data return on the IDX consumer sector and construction stock index from 2011 to 2016.

\section{RESEARCH METHOD}

In general, the theory related to investing inment management experience very rapid development from time to time. At least there are five theories that can be useful to underlie investment management. These theories consist of portfolio theory, capital market theory, valuate of derivative securities.

The Variable in this study is a risk and return. Based on the variable which was stated, 
the design of the study began by collecting data in a documenting way in the Bloomberg terminal, then proceeded to analyze the data with the CAPM and APM methods to report the results of the research. A Risk is a form of uncertainty about a situation that will occur later with a decision taken based on a consideration (Fahmi, 2009). Another understanding is the deviation between the expected return measured by beta. Expected return is giving the weight of the average return by using the probability weight. This measures the average or central tendency of the return probability distribution. Expected is the sum of the results of the multiplication of rate of return that may occur in a period with probability.

The population here is the construction sector industrial company listed on the Indonesia Stock Exchange. In 2011-2016 there were 4 issuers. The sampling method uses purposive sampling, with the sample selection criteria of this study: companies classified as consumer goods industries and construction sectors that have gone public, and are LQ45. Issue complete, clear financial statements and publish their financial statements from 2011-2016. Data is taken from the Bloomberg webpage.

The Analysis which used in this study is using the capital asset pricing model - Capital Asset Pricing Model and Arbitrage Pricing Theory. The CAPM definition is an asset risk and profit valuation theory based on beta coefficients. CAPM is a model for determining the price of an asset. This model bases itself on equilibrium conditions the level of profit indicated by investors for a stock will be affected by that risk. The risk here is no longer interpreted as the standard deviation of the profit level but is measured by beta. The use of this parameter is consistent with portfolio theory which says that if the investor holds a market portfolio, then this risk contribution is nothing but beta.

CAPM actually forms the model using a series of simplification assumptions. Testing a model is not realistic about the assumptions used, but on how precisely the model reflects reality. Nevertheless, it is explained how if some of these assumptions are relaxed, namely how if short selling is not permitted and what if there is no Rr. The result turns out that the standard CAPM does not experience much change in risk-free, which is used in this study is FR0031 which is government bond that distributes fixed rate coupons by $11 \%$ every quarter and mature in 2020.

CAPM in mathematics: $E(r i)=R f+[E(r m)-R f] b j$

Where:

bj = is a systematic independent variable that determines the $\mathrm{E}(\mathrm{ri})$ or expected profit of an asset or a risk-measure of each security.

$\mathrm{Rf}=$ risk-free asset

$\mathrm{E}(\mathrm{rm}) \quad=$ estimated market risk

$\mathrm{E}(\mathrm{rm})-\mathrm{R}=$ investor risk premium

Variables that related to the CAPM formula according to Arianto are as follows:

\section{Individual Stock Returns (Ri)}

Sharpe et al. (1999) stated that stock returns will be influenced by two basic characters, which are namely systemic risk and stock liquidity and the research conducted by Saputra, Elly, and Leng (2002) succeded in proving that systemic risk and stock liquidity as measured by the bid-ask spread has an effect significant on stock returns from business entities that go public in Indonesia.

Individual stock returns can be calculated by the following formula:

Return Saham Individual $(\mathrm{Ri})=\frac{\mathrm{D}_{1}+\mathrm{P}_{1}-\mathrm{P}_{\mathrm{t}-1}}{\mathrm{P}_{\mathrm{t}-1}}$ Where:

$$
\begin{array}{ll}
\mathrm{Pt} & =\text { Price for time }(\mathrm{t}) \\
\mathrm{Pt}-1 & =\text { Price for previous time } \\
\mathrm{D} 1 & =\text { Dividend }
\end{array}
$$

\section{Risk-Free (Rf)}

The result of investment without risk is the minimum return expected by investors according to the Treynor and Sharpe (Sharpe et al., 1999) models. This riskless investment object 
includes bank deposits and Indonesia bank certificates (SBI). Deposit rate and S.

\section{Market Return (Rm)}

Market Return is calculated by the following formula:

$$
\mathrm{Rm}=\frac{\text { IHSGt }- \text { IHSGt }-1}{\text { IHSGt }-1}
$$

Where:

IHSGt = Composite Stock Price Index at the end of period $t$

IHSG-1 = Composite Stock Price Index for the previous period.

Beta $(\beta \mathrm{i})$

Beta is calculated by the following formula (Samsul, 2006)

$$
\beta \mathrm{i}=\frac{\text { Covariance }}{\text { Market Variance }}
$$

According to Supranto, (2001:183) Covariance formula as follows:

$$
\text { Covarians }=\frac{1}{n} \sum_{i=1}^{n} \mathrm{X}_{i} \mathrm{Y}_{i}-\sum_{i=1}^{n} \mathrm{X}_{i} \sum_{i=1}^{n} \mathrm{Y}_{i} / \mathrm{n}
$$

According to Irianto, (2004), Varian's formula as follows:

$$
\text { Varians }=\frac{\sum(\mathrm{x}-\bar{x})^{2}}{n-1}
$$

\section{Expected Return (Eri)}

Once $\mathrm{Ri}, \mathrm{Rf}, \mathrm{Rm}$, and $\beta \mathrm{i}$ are known, the CAPM formulation is used to determine the expected return of the CAPM formula as follows:

$$
\mathrm{E}\left(\mathrm{R}_{\mathrm{i}}\right)=\bar{R}_{\mathrm{f}}+\beta_{\mathrm{i}}\left(\bar{R}_{\mathrm{m}}-\bar{R}_{\mathrm{f}}\right)
$$

Where:

$\mathrm{E}(\mathrm{Ri})=$ Return is expected as a minimum return

$\beta \mathrm{i}=$ Beta shares

$\bar{R}_{\mathrm{f}} \quad=$ Average level of risk-free return

$\bar{R}_{\mathrm{m}} \quad=$ Average market return

\section{Arbitrage Pricing Theory}

This theory was made by Stephen Ross in 1976. It is based on the law of one price, which states that two identical assets cannot be sold at different prices. APT assumes that asset returns are linearly related to a number of indices where each index represents a factor that influences return on an asset. Market participants develop their expectations about sensitivity to factors. APT states that the equilibrium of market prices will adjust to eliminate arbitrage opportunities that indicate a situation where a zero investment portfolio can be formed which will generate risk-free profits.

\section{RESULT AND DISCUSSION}

This study wants to test the overall of the consumer goods industry sector companies and construction sector companies listed on the Indonesia Stock Exchange. However, only 4 issuers from companies that have been tested for the company's fundamentals are only taken and are consistently included in LQ45. LQ45 itself stands for Liquidity 45 which consists of 45 issuers' shares which are re-evaluated every few months. The rate of return is the result obtained from the investment. Systematically the monthly return of individual shares is formulated as follows:

Return Saham Individual $(\mathrm{Ri})=\frac{\mathrm{D}_{1}+\mathrm{P}_{1}-\mathrm{P}_{\mathrm{t}-1}}{\mathrm{P}_{\mathrm{t}-1}}$ Where:

$\mathrm{Pt} \quad=$ Price for time $(\mathrm{t})$

Pt-1 = Price for previous time

D1 = Dividend

By using stock prices, the results of the calculation of stock returns during 2011-2016 are obtained. After it is known that the individual returns of four issuers during 2011-2016 are then regressed using eviews. By using the Composite Stock Price Index (CSPI) market performance, the results were obtained: 
Table 1. Estimation of stock returns during 2011-2016

\begin{tabular}{|c|c|c|c|c|c|c|c|c|c|}
\hline \multirow{2}{*}{ No } & \multirow{2}{*}{ Stock } & \multicolumn{2}{|c|}{ AJ } & \multicolumn{2}{|c|}{ CAPM \& ABT } & \multicolumn{2}{|c|}{ BETA } & \multicolumn{2}{|c|}{ INFLATION } \\
\hline & & Coef & Prob & Coef & Prob & Coef & Prob & Coef & Prob \\
\hline 1 & PTPP & 0.128 & 0.002 & 0.125 & 0.003 & 1.969 & 0.000 & 0.019 & 0.434 \\
\hline 2 & WIKA & 0.090 & 0.006 & 0.086 & 0.008 & 1.677 & 0.000 & 0.0312 & 0.118 \\
\hline 3 & ICBP & 0.020 & 0.309 & 0.020 & 0.311 & 1.049 & 0.000 & -0.001 & 0.927 \\
\hline 4 & INDF & 0.008 & 0.675 & 0.008 & 0.676 & 1.045 & 0.000 & -0.000 & 0.982 \\
\hline
\end{tabular}

Note: Prob t Stat Significant on Alpha 5\%

By using the Composite Stock Price Index (IHSG) market return, with a significance level of $5 \%$ from the Output Table, the analysis with alpha Jensen's model obtained positive alpha (a) values for all the shares studied and the Composite Stock Price Index, which means the return generated by these stocks are higher than the market. CAPM beta value on these stocks shows significant results and a positive effect on returns. Where in the shares of PTPP, WIKA, ICBP, and INDF the resulting beta coefficients are 1.9, 1.6, 1.04 and 1.04 times greater than the market. This means that if the market experiences a 1 percent increase, the return of each of these stocks will increase to 1.9, 1.6, 1.04 and 1.04 percent of the market. The performance of these stocks is indicated to be able to produce abnormal returns (abnormal) in an inefficient market. In this model, Beta has a significant and positive influence on the return of these stocks. But with a greater beta value, the performance of the two mutual funds is better than in this model. However, in the Inflation variable, all the shares studied produced a non-significant relationship (No Sig), except that there were differences in influence, namely for PTPP and WIKA shares to have a positive influence while ICBP and INDF had negative effects. From the results of testing the 2 alpha Jensen models above, namely with the Capital Asset Pricing Model (CAPM) and Arbitrage Pricing Theory (APT), the construction sector shares are PTPP and WIKA. The potential generated by these stocks can be greater than Risk-Free, namely FR0031 and Benchmark, namely the JCI.

This can be seen in the alpha and beta values generated in the model tend to be larger, which indicates a greater abnormal return occurs in an inefficient market. In addition, because they are a stock investment instrument, it does produce a higher return potential which is normal compared to other investment instruments.

\section{CONCLUSION}

Based on the research that has been done, it can be concluded that:

1. Inflation variables have no significant effect on 2 issuers in the construction sector, namely WIKA and PTPP and have a positive effect.

2. Inflation variables have no significant effect on issuers in the consumption sector, namely INDF and ICBP and have a negative effect.

\section{RECOMMENDATION}

From the results of the research conducted, the authors provide several suggestions, namely: Construction industry sector companies such as Wijaya Karya Tbk, and PP (Persero) Tbk. those listed on the Indonesia Stock Exchange (IDX) are affected by macroeconomic factors on the return of shares in the company and the construction sector shares have a higher return than shares in the consumption sector due to the tendency of Indonesia in this period in building infrastructure. So that there needs to be anticipation from the government to prepare for a decrease in stock value due to the transfer of focus from the government so that investors do not feel harmed. The government is also expected to be able to keep the inflation rate at a stable level in 
order to boost the economy and not undermine share values due to increased inflation.

\section{REFERENCES}

Fahmi, I., and Hadi, Y.L. (2009). Teori Portofolio dan Analisis Investasi. Bandung: Alfabeta.

Gumanti, T.A. (2011). Manajemen Investasi: Konsep, Teori dan Aplikasi. Jakarta: Mitra Wacana Media.

Husnan, S. (2009). Dasar-dasar Teori Portofolio dan Analisis Sekuritas. Yogyakarta: Penerbit UPP STIM YKPN.

Irianto, A. (2004). Konsep Dasar dan Aplikasinya. Edisi 1. Jakarta: Prenada.

Ross, S.A. (1976). The arbitrage theory of capital asset pricing. Journal of Economic Theory, Elsevier. 13(3), 341-360.

Samsul, M. (2006). Pasar Modal dan Manajemen Portofolio. Jakarta: Erlangga.

Saputra, K.A., Elly, and Leng, P. (2002). Pengaruh Risiko Sistematis Dan Likuiditas Terhadap Tingkat Pengembalian Saham Badan-Badan Usaha Yang Go-Public Di Bursa Efek Jakarta Pada Tahun 1999. Jurnal Manajemen dan Kewirausahaan. Petra Christian University Siwalankerto. Surabaya.

Sharpe, W., Alexander, G.J., and Bailey, J.W. (1999). Investments 6th Edition. Prentice-Hall, Englewood Cliffs.

Shim, J.K., and Siegel, J.G. (1999). Operations Management. Hauppauge, NY: Barron's Educational Series

Supranto, J. (2001). Statistik Teori dan Aplikasi. Edisi 6. Jakarta: Erlangga. 